\title{
Unscientific Visual Representations Used for the "Egg Aging" Campaign in 2010s Japan
}

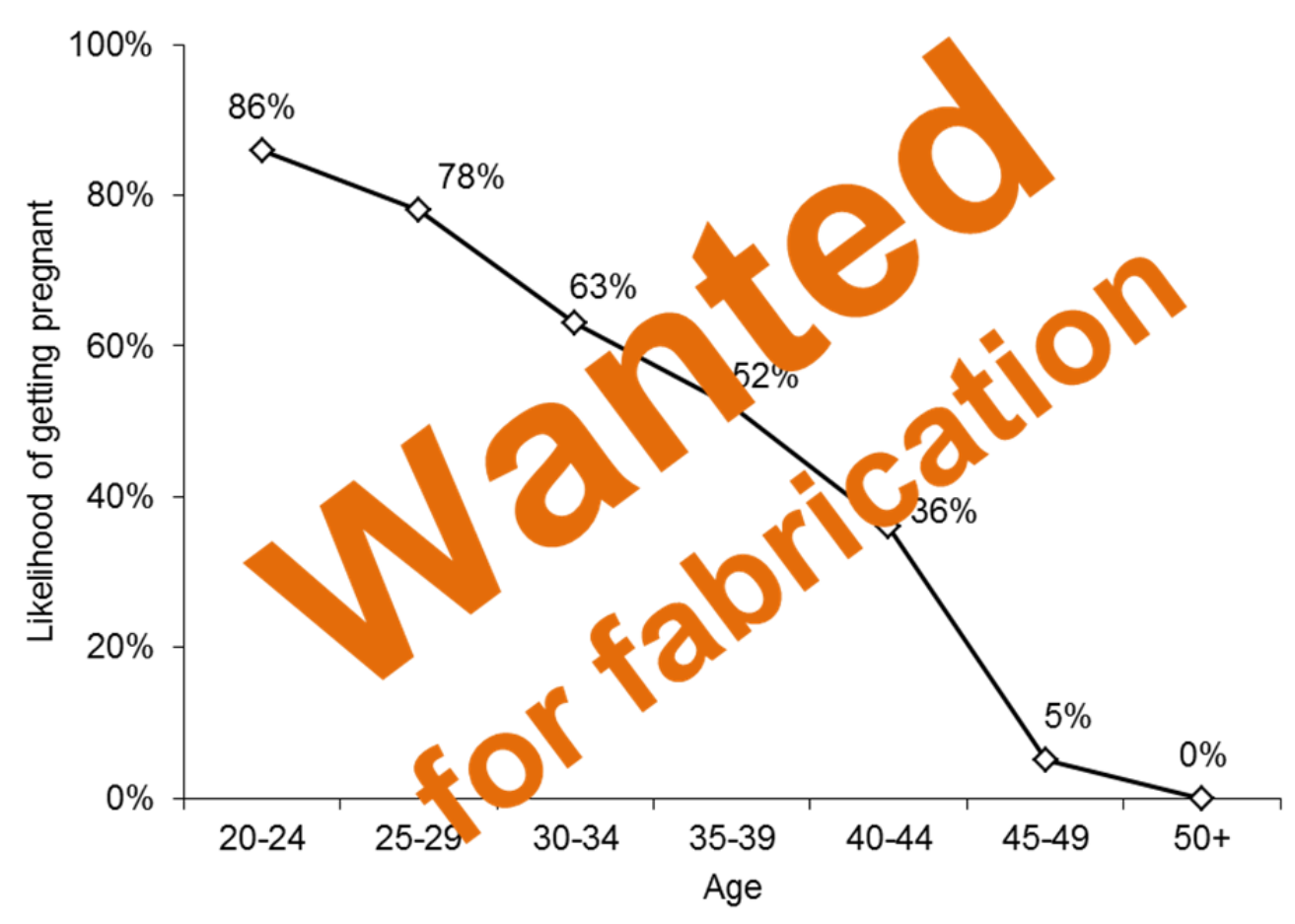

TANAKA Sigeto

(Tohoku University)

August 2018

Funding: Japan Society for the Promotion of Science, KAKENHI (FY2017-FY2019):

非科学的知識の生産・流通と「卵子の老化」パニック (grant number 17K02069) 


\section{Egg aging campaign and Japanese pronatalist policy}

Japan has experienced floods of fake knowledge about human reproduction in recent times. Most of them are created by professionals in the fields of obstetrics, gynecology, and reproductive medicine and spread widely through a mass media campaign backed by academic associations. Such a knowledge has also been used by the government as scientific evidence to justify encouragement of pregnancy and childbirth for young women [1].

“Egg aging" (卵子の老化) has been the key concept in the campaign. This concept is originally a term of biology for the degeneration of eggs (or female germ cells) owing to a long delay in the process of meiotic division [2]. The concept is found in Japanese medical literature of the 1970s [3]. In the early 2000s, it appeared in books targeting a general audience [4]; however, the arguments in that period were moderate and focused on the difficulties related to infertility treatment for women in their 40s. Before 2010, it was rare that the concept of egg aging was used with the same connotation as today.

In the 2010s, medical discourse shifted to emphasize the association between fertility decline and women's age. Professionals and mass media have created visual representations to emphasize how rapidly women's fertility decreases from their 20 s to 30 s.

As it acquired popularity, the concept widened its connotation. "Egg aging" has been mixed up with the findings that female germ cells are generated before a woman's birth and then continue to decrease in number [5]. It has also been incorporated with reports that infertility treatment often fails with unidentified causes when the female patient is advanced in age [6]. Consequently, the term "egg aging" today is not limited to the degeneration of germ cells, but covers a wide range of fertility problems experienced by women of an advanced age. It now serves as a magic phrase to represent many aspects of latent biological mechanisms of declining fertility [7].

In the course of the media campaign, fake knowledge about human reproduction has become popular in books, magazines, and websites giving an impression that it is based on scientific grounds. These are targeted at youths' perception of their body and thereby have an impact on their sexual behavior and family planning. We can regard this as a violation against reproductive rights because it disrupts the reproductive decision-making process with misinformation. It also damages public trust in the medical profession, which will eventually harm the social health system.
The "egg aging" campaign also has a political aspect because it has guided public attention to the linkage between age-related decline in biological fertility of persons and the birthrate decline in these decades of the country. Considering women's average age at first childbirth as old as 30 years today, people are surprised at the new biological knowledge about "egg aging." They are worried that the recent generations would miss the opportunity to have children, without the awareness of the suitable period for pregnancy in their life. This idea brought about a political movement to educate people on egg aging. This movement is related not only to health matters, but also to a new pronatalist policy encouraging women to become pregnant earlier in life to stop the population shrinking of the Japanese society.

Since the Cabinet approved the new administration strategy described in the Outline of Measures against the Declining Birthrate [8] in March 20, 2015, such a pronatalist policy has been realized in school education, in "life-planning" guidance by local governments, and in messages broadcasted by mass media. Many visual representations of a dubious origin have been produced and used.

This brochure, Unscientific Visual Representations Used for the Egg Aging Campaign in 2010s Japan, is a product of the research project "Unscientific knowledge and the egg aging panic" (非科学的知識の生産・流通と「卵子の 老化」パニック) funded by the Japan Society for the Promotion of Science (KAKENHI \#17K02069 for fiscal 2017-2019). This project is run by Tanaka Sigeto, an associate professor at Tohoku University, to explore the courses, contexts, and consequences of the egg aging campaign. According to a literature survey of both academic and popular writings, this brochure introduces some instances of visual representations used in the campaign and explains how they have been widespread in the Japanese society to affect governmental policies and public opinions.

The project has collected information via social media, such as Twitter, besides literature reviews. This brochure owes the corporation with the informants. The author also thanks the corporation of those who participated in the group “高校保健 - 副教材の中止 - 回 収を求める会”, which started in September 2015 to protest against the use of unscientific contents in a high school supplementary textbook for health education (see pages 6 and 10 of this brochure). Information is still wanted to trace the history of unscientific use of knowledge and to detect emergence of new discourses related to fertility issues (see p. 12). 


\section{Misused results from a multilingual cross-national survey on fertility awareness}

The egg aging campaign in Japan was triggered by the results from the cross-national survey, the International Fertility Decision-Making Study (IFDMS), conducted in 2009-2010 by a Cardiff University research group supported by the global pharmaceutical company Merck Serono. The results of the IFDMS showed that respondents in Japan exhibited a low level of fertility awareness measured using the Cardiff Fertility Knowledge Scale (CFKS).

The findings of the IFDMS were published in an academic journal [9] in 2013. However, before then, it had already been used in lobbying activities and leaked to the media. In February 2011, the head of the IFDMS project, Jacky Boivin, visited Japan and held lectures for the media and for members of the Diet [1]. Thereafter, the results from the IFDMS were featured in newspapers, popular magazines [10], and TV programs [5]. These media contents resulted in the widely accepted view today that the Japanese have incorrect or distorted knowledge about pregnancy and childbirth.

The IFDMS also influenced the views of the government. In 2012, Diet member Noda Seiko mentioned the findings of the IFDMS in a question to the Cabinet [11]. In 2014, Saito Hidekazu, a doctor at the National Center for Child Health and Development, included Figure 1 in his presentation at a governmental conference on population policies [12]. On the graph, which had been reproduced from the original paper [9], Saito added explanations in Japanese that Japan's CFKS score was the second lowest among the surveyed countries, next to Turkey; therefore, education on human fertility was needed. Following the opinions by Noda and Saito, the government aimed to improve education on fertility. The 2015 Outline of Measures against the Declining Birthrate [8] set the numerical goal based on the results of the IFDMS.

Today, it is known that the IFDMS has many defects, including as follows; its results are unreliable [13] [14]:

$>$ Incomparability of the samples among countries

$>$ Insufficient translation process to ensure comparability among languages

$>$ No pretest for non-English questionnaires

$>$ Unnatural phrases and spelling errors in the Japanese version of the questionnaire

$>$ Questions asking a male respondent about why he is not pregnant

$>$ Improper translations in the CFKS

$>$ Different ordering of the items of the CFKS between the English and Japanese versions

$>$ Low statistical reliability of the CFKS total score

$>$ Non-replicability of the study because the questionnaires are not opened

Nevertheless, the study has been treated as offering credible scientific evidence. By 2015, the notion that the Japanese have the lowest level of fertility literacy among countries of the world had become already widespread. When criticism emerged against the IFDMS in 2015 [15], it was too late to convert the approved policy and the established self-image of Japan as a society lacking knowledge about fertility and childbirth.

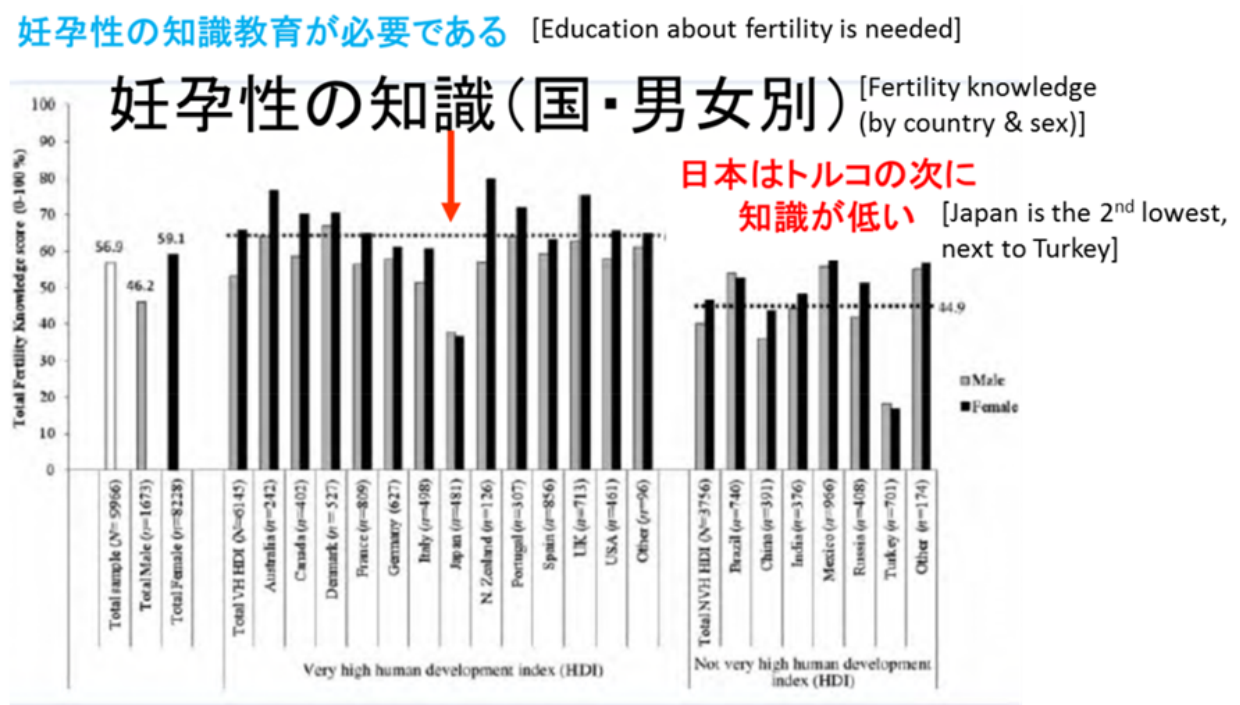

Human R1eproduction,28:385-397, 2013

Source: Saito [12], a document prepared for a governmental conference in 2014.

Japanese texts are added by Saito Hidekazu (with my translation in English).

Figure 1: Mean Cardiff Fertility Knowledge Scale scores by country and sex according to the IFDMS 


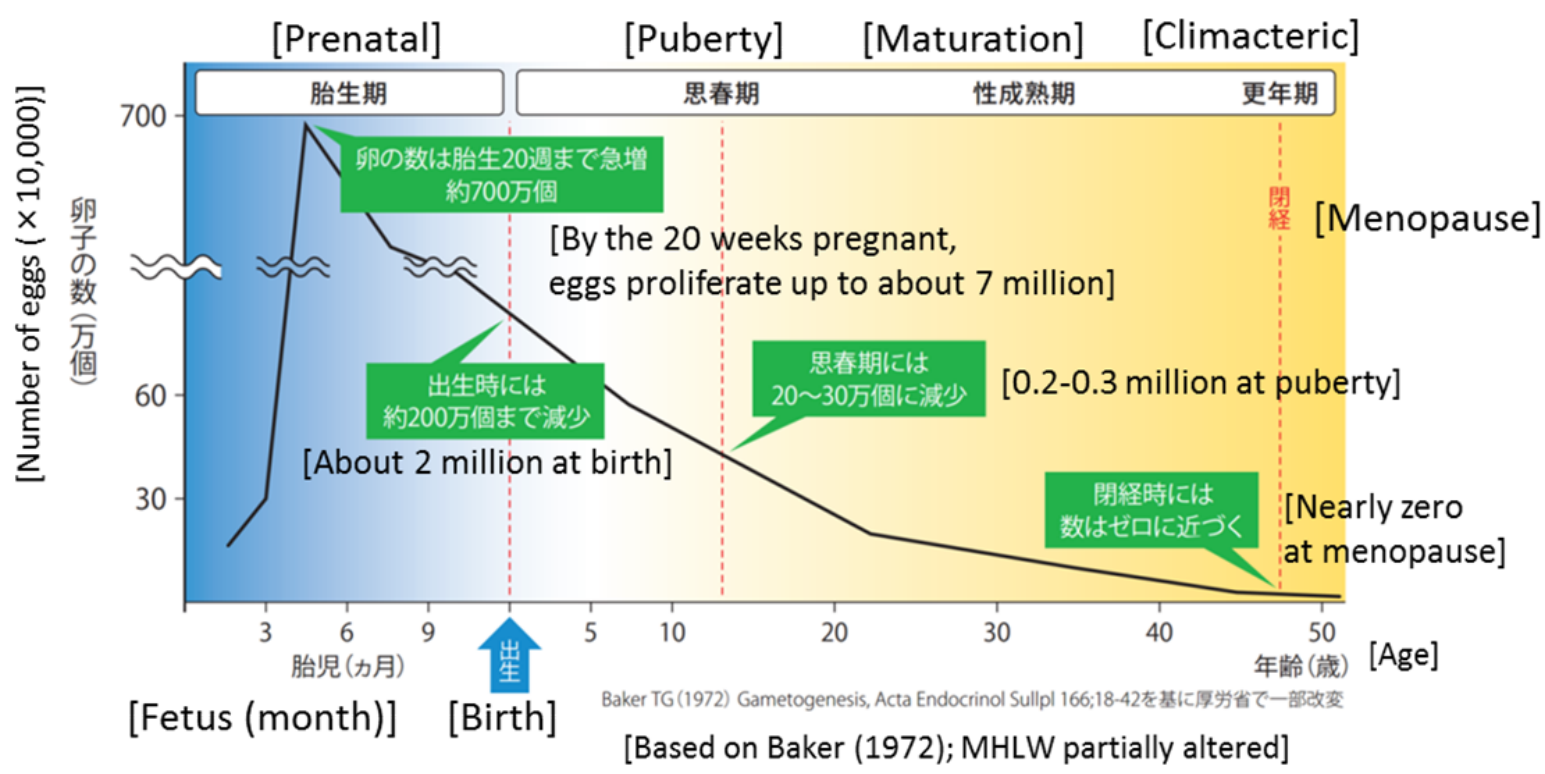

Source: Website of the Ministry of Health, Labour, and Welfare [16]. English translation is mine.

Figure 2: Distorted graph on women's age and number of eggs

Figure 2 shows a graph of a woman's age and number of eggs in her body. It was included in a booklet to teach the general audience medical knowledge about human bodies, focusing on sex differences regarding reproduction [16], retrieved from the official website of the Ministry of Health, Labour, and Welfare (MHLW). This booklet was produced by a research group backed by the MHLW research fund for FY2012 [17].

This kind of graph on age and the number of eggs is one of the standard items frequently featured for the egg aging campaign. It usually appears in combination with graphs of age-fertility profile as we will see in the following sections in this brochure to substantiate the premise that a woman loses her fertility as she ages so that it is better to have children as young as possible.

This graph is falsified. Although the legend below the graph $^{1}$ refers to the paper by Baker, ${ }^{2}$ the curve of Figure 2 is quite different from that in the paper (Figure $3)$. The most remarkable difference is that the eggs continue to decrease during the 20s and 30s in Figure 2,

\footnotetext{
1 The citation contains a mistake in the journal title, as we will see in p. 11.

2 The same graph appeared in the papers by Baker in 1971 [18] and 1972 [19]. The graph combined results from two papers: Baker's paper in 1963 for unborn fetuses and newborn babies [20] and Block's paper in 1952 for older women [21]. The graph visualized the separation between the sources by cutting the $x$-axis and the curve just after the point of birth. Because Baker [18] [19] did not explain the data, the original papers [20] [21] must be read to know what they discovered.
}

in contrast to the almost constant level maintained during this period in Figure 3. Furthermore, almost all points are plotted at different positions between the two figures. The legend says the MHLW committed the alteration.

Figure 2 also has a mistake that is apparent even without reading Baker's paper. Although it describes in a balloon that a female baby has about two million eggs when she is born, the $y$ value is obviously less than one million at the time of birth. In sum, Figure 2 is far from showing scientific research results.

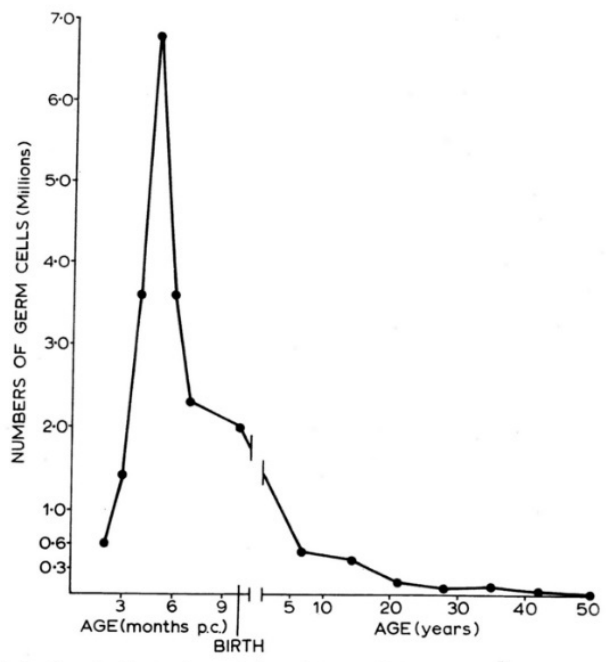
Fig. 1. Fluctuations in the total population of germ cells in the human ovary during repro-
ductive life. Data for prenatal period derived from Baker $^{3}$ and for children and adults from
Block.24 Source: Baker [18]

Figure 3: Women's age and number of germ cells 
Many publications have used graphs similar to Figure 2. They exhibit a wide variety of appearance and citation. Some of them are not so much distorted and provide correct citations to Baker's paper. The others severely altered the curve or provided inappropriate citations.

Figure 4 is presented in the Infertility Q\&A website [22] by the Japan Society for Reproductive Medicine (JSRM) in 2013. The same graph appears in JSRM's textbook [23] and a handbook for doctors [24], which we will revisit in p. 8. The peak value in Figure 4 is higher than that in Figure 3. The points are plotted at wrong locations for the 9th-month fetus, for the time of birth $(x=0)$, and for the ages of 10 years and over. In particular, the number of egg cells by the age of 30 years seems to have been decreased to almost zero. Because the citation for the graph by the JSRM [22] only refers to the 1963 paper by Baker [20], which does not include results for adults, the right part of the curve is not backed with data.

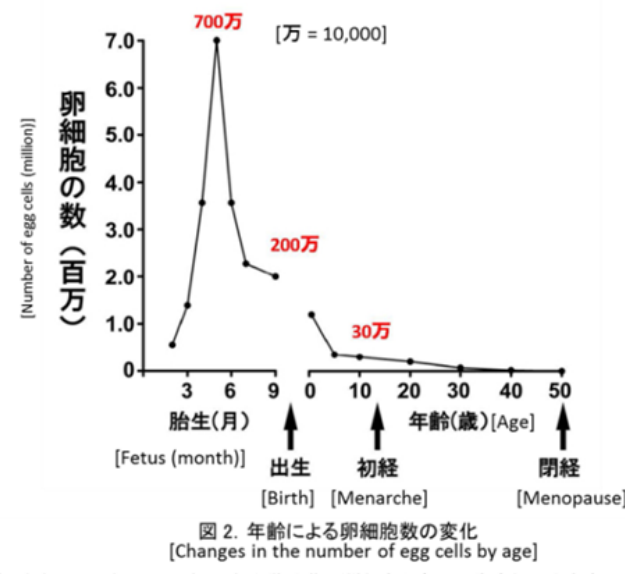

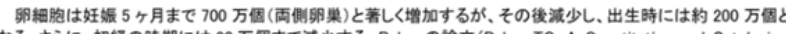

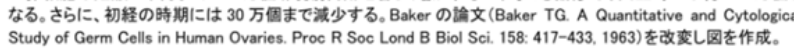

Source: Japan Society for Reproductive Medicine [22].

English translation is mine.

Figure 4: Fabricated graph of the number of egg cells

We should also focus on the usage of this kind of graph as evidence for the argument that a woman's fertility rapidly decreases as she ages, and this decrease begins at a very early period of her life. This argument might have been started with the 2009 book by Dr. Asada Yoshimasa [25] in which he provided information that given the stock of 300,000 eggs a woman has when she is 12 years old, she subsequently loses 1,000 eggs every month so that the stock will run out when she becomes 37 years old. Unfortunately, Asada gave no bibliographical reference for his argument.

It is doubtful that such an explanation helps understand fertility problems. Cited studies on the number of eggs [20] [21] did not address fertility. Indeed, although a large number of eggs disappear in one's teen ages according to Figure 3, those ages are also the stage for development of reproductive capacity for humans according to biology.
Notably, there is a difficulty in obtaining sample ovaries for determining the average number of eggs (or follicles). To obtain "normal" ovaries for the result presented in Figure 3, Block [21] screened cases of sudden deaths and selected 43 cases aged from 6 to 44 years. The counted number of eggs greatly varied among cases. We should be aware of errors owing to the small sample size, as well as the preliminary statistical method.

There have been studies that complement Block's findings. Faddy et al. [26] reported the result of estimation of the number of eggs in the ovaries reusing Block's data and some additional data from other sources. They adopted a statistical model with linear equations to predict the logarithmic number of eggs. The results implied that the coefficient for the effect of age switches at the age of 37.5 years - that is, the reduction rate of the number of eggs accelerates after the woman reaches the age of 37 years.

The result by Faddy et al. has also been reproduced in distorted ways. Figure 5 shows a graph in an article by Dr. Koike Koji published in 2000 on the official journal of the Japan Society of Obstetrics and Gynecology (JSOG) [27]. Although it has no citation, the curve on the graph is similar to a graph by te Velde et al. [28], which cited Faddy et al. It is a composite of eight small segments of line, in contrast to the result by Faddy et al. made from two lines concatenated at the age of 37.5 years. Thus, in Figure 5, some points are plotted in the positions where no point was plotted by Faddy et al., such as $18,31,41$, and 45 . In addition, while the estimation by Faddy et al. was for the period after one's birth, Figure 5 extends the curve to the prenatal period, seemingly based on Baker's work [20]. Furthermore, at the age of 31 years, a note "Decrease Ferility" is inserted. Te Velde et al. [28] suggest that it is affected by the manipulated data by Bendel \& Hua [29], which we will see in the next page.

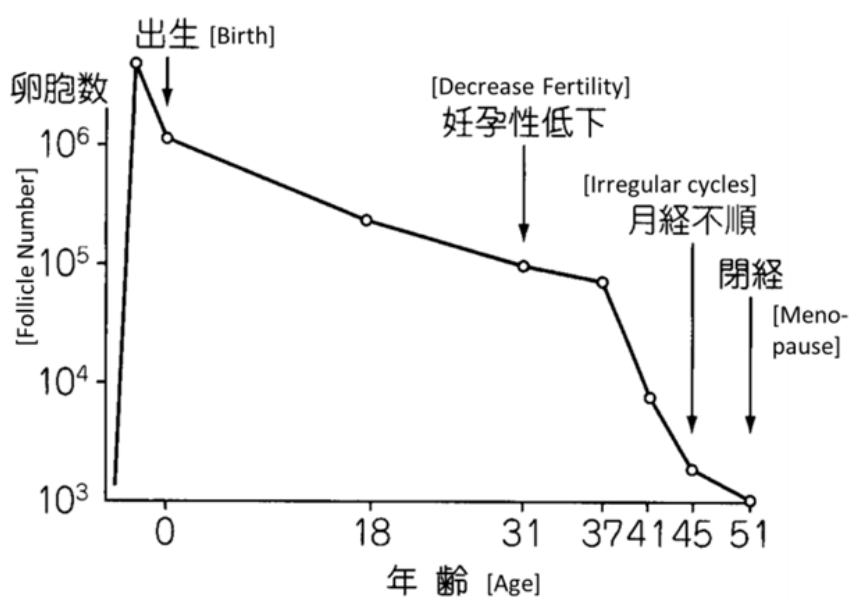

Source: Koike [27]. English text is from te Velde et al. [28].

Figure 5: Compounded graph of the number of follicles 


\section{Falsified graph of women's fertility with its peak at the age of 22 years}

The egg aging campaign has also featured graphs that gave a direct impression of the declining fertility with the advancing age of a woman.

Figure 6 shows a falsified graph that was used in a petition by nine academic associations, including the JSOG, to seek actions from the government to introduce medical knowledge about human reproduction in formal school education [30]. In March 2, 2015, they submitted the petition to Arimura Haruko, then the Minister of State for Measures for Declining Birthrate.

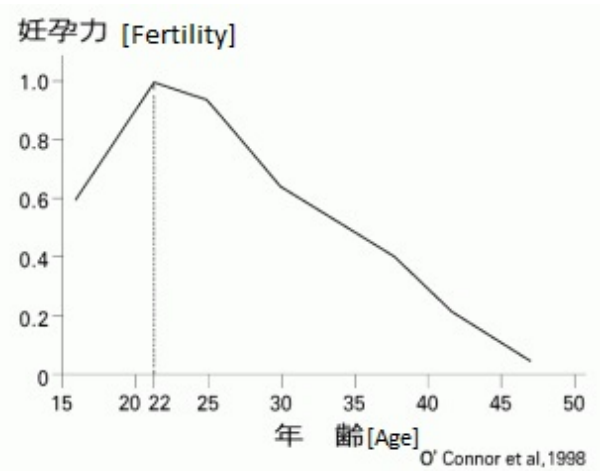

Source: http://www.jfpa.or.jp/paper/main/000430.html English translations are mine.

Figure 6: Graph of women's fertility used in the petition by professional associations in 2015 [30]

Figure 6 was derived from a statistical estimation by Bendel and Hua in 1978 [29] on fecundability (monthly probability of conception). Because of defects in the method for processing the original data, their result was far from representing women's biological capacity of conception. Specifically, regarding the data for women aged $\geq 25$ years, Bendel and Hua only used data for women who married before their mid-20s. The original data [31] were from surveys of American Hutterites ${ }^{3}$ in the 1950s and 1960s, including women who married in their late 20s and 30s (two black dotted lines in Figure 7), who exhibited high fertility rates at least in the newlywed period. However, these were excluded from Bendel and Hua's estimation. They performed their analysis only on data of women who married early (two solid blue lines in Figure 7). The result consequently indicated that fecundability declines significantly before the mid-30s, reflecting the fertility rates declining along with the increasing time passed from the day of marriage [32]. Generally, couples tend to be the most fertile in their newlywed period and to become less fertile over time; however, this does not necessarily represent an age-related decline of biological fertility. Rather, it may be attributable to their inactive sexual

\footnotetext{
${ }^{3}$ Hutterite is a religious group of Anabaptist known to have a high fertility. Its origin was the Central Europe in the 16th century. A branch of it migrated in North America in the late 19th century.
}

behavior after the longer duration of continuous marital relationship.

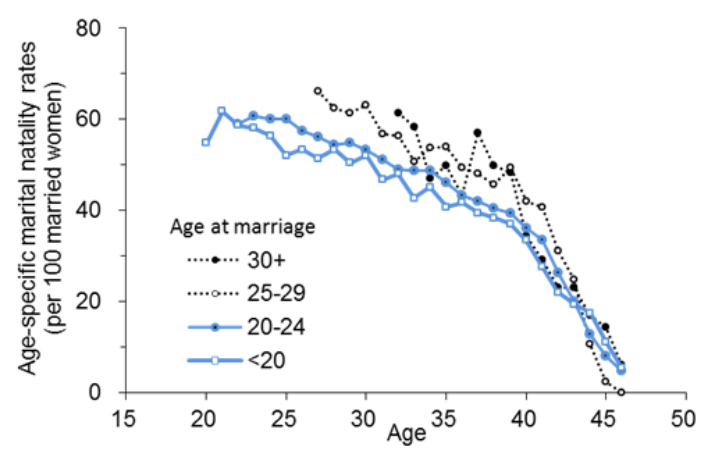

Plotted are 3-year moving averages, calculated in accordance with the data by Sheps [31]. See Tanaka [1] [32].

Figure 7: Age-specific marital fertility rates for Hutterite women (1950s and 1960s)

Eleven years after the publication of the paper by Bendel and Hua [29], Wood [33] used their results to illustrate an age-fecundability profile after manipulating the curve to make fecundability peak at the age of 22 years. This curve was then inaccurately copied by O'Connor et al. [34]. The graph that appeared in the petition (Figure 6) was made by Dr. Yoshimura Yasunori, a professor emeritus at Keio University. Yoshimura [35] simplified the curve by extracting only seven points and shifting four of them (each within the 20s-30s range) left along the $x$-axis. These modifications allowed the curve to show that women's fertility enters a steep downhill immediately after the peak at the age of 22 years.

It is important that the flaw of Bendel and Hua's interpretation of the data had already been criticized in 1979 [36]. Since then, Bendel and Hua's study has been cited only 13 times (according to Web of Science in February 3, 2016), and none of the 13 works favorably appraised the study after assessing its data and method [32]. The result of the citation search thus implies that the study does not warrant an uncritical reference as scientific evidence.

A graph similar to Figure 6 appeared in a high school supplementary textbook for health education [37] published in August 2015 by the Ministry of Education, Culture, Sports, Science, and Technology. Minister Arimura described the textbook as in line with the government's new Outline of policies against low birthrates [8]. When newspapers reported the publication of the textbook, it received criticism for the exhibition of gender bias and for the government's apparent motive to promote childbirth at a young age as a means to raise the nation's birthrate [14]. 


\section{Fabricated curve for a woman's likelihood of getting pregnant}

Figure 8 is adapted from images on the Web. It looks as if a woman's "likelihood of getting pregnant" linearly decreases along with her advancing of age. The downward curve is always used in combination with an upward curve for the "likelihood of infertility." Such charts are widespread on the Internet. A Google image search yielded more than 200 hits of the chart (November 5, 2016).

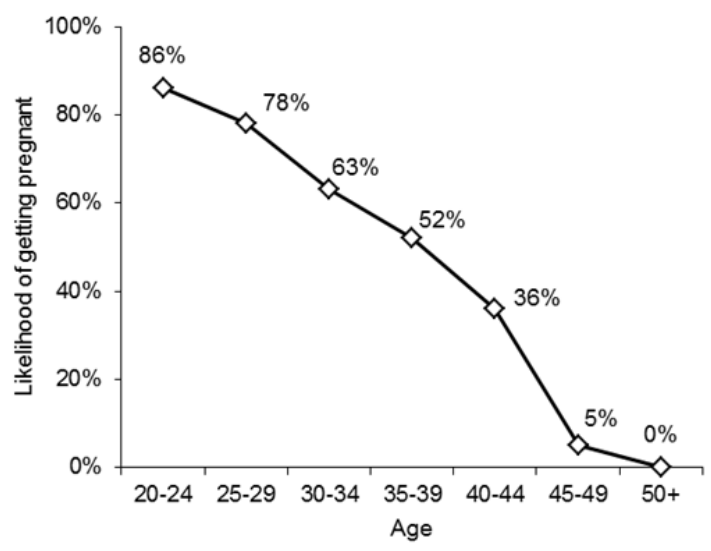

Created on the basis of images found on the Web [38].

Figure 8: "Likelihood of getting pregnant" curve

Some versions of the charts refer to Helen A. Carcio's book, Management of the Infertile Woman [39]. A table in that book contains four numbers (i.e., 86, 78, 63, and 52) under the heading of "Percent Conceiving Within 12 Months" (Table 1). These data are identical to the first four points for the 20s and 30s on the curve in Figure 8. However, the book specified no data source. It is not clear where the four percentages came from [38].

The other three values on the curve come from M. Sara Rosenthal's The Fertility Sourcebook. The book's second edition in 1998 [40] contains a table of "Likelihood of Getting Pregnant," which includes the numbers of $100 \%$, $94 \%, 86 \%, 70 \%, 36 \%, 5 \%$, and $0 \%$ (Table 2). The last three values are the same as the values for the age classes 40 44, 45-49, and $\geq 50$ in Figure 8.

Rosenthal's table is problematic because it indicates no likelihood of getting pregnant in reality. These figures are based on age-specific marital fertility rates from several natural fertility ${ }^{4}$ populations [42] converted into ratios to the baseline at the early 20s. Accordingly, they are not proper figures to indicate one's "likelihood of getting pregnant." For instance, the value is " $100 \%$ " for women aged 20-24 years because it is selected as the baseline for comparison. For women aged 45-49 years, the value is " $5 \%$ " because the reported average marital fertility rate [42] for these ages (0.024) is about $5.2 \%$ of

${ }^{4}$ Natural fertility is a demographic term that means people do not intentionally limit the number of their children [41]. the rate at the baseline ( 0.460 for the early $20 \mathrm{~s})$. Thus, the values do not indicate the probabilities at which women get pregnant. In this respect, Rosenthal falsified the heading of the table. In addition, Rosenthal appended a note "Presuming optimum health" below the table; however, no such an information is found in the original data [41].

In conclusion, there is no scientific ground found for the "Likelihood of getting pregnant" curve in Figure 8. Among the seven points plotted on the curve, four are of an unidentified origin. The other three never indicate the likelihood of getting pregnant. Unfortunately, it is unknown who combined these data into a curve. Nevertheless, Carcio and Rosenthal are responsible for publishing those groundless or falsified figures.

The groundless linearly declining curve has been widely used for long years in the field of obstetrics and gynecology. In the United States, a similar curve appeared in a book jointly written by a CNN news anchor and a doctor of the New York University Fertility Center [43]. Articles in a German academic journal quoted the figures [38]. In Japan, Yamagata [17] provided an example of an abusive use in education to encourage young women to get pregnant earlier. Fukuoka City [44] recently featured a similar chart in a movie for life-planning education.

Table 1: "Probability of pregnancy with advancing age" by Carcio's Management of the Infertile Woman [39] p. 39

\begin{tabular}{cc}
\hline Age Group, Years & Percent Conceiving Within 12 Months \\
\hline $20-24$ & 86 \\
$25-29$ & 78 \\
$30-34$ & 63 \\
$35-39$ & 52 \\
\hline
\end{tabular}

Table 2: "Fertility through the ages" by Rosenthal (1998) in The Fertility Sourcebook (2nd ed.) [40] p. 5

\begin{tabular}{cc}
\hline Age & Likelihood of Getting Pregnant* \\
\hline $20-24$ & $100 \%$ \\
$25-29$ & $94 \%$ \\
$30-34$ & $86 \%$ \\
$35-39$ & $70 \%$ \\
$40-44$ & $36 \%$ \\
$45-49$ & $5 \%$ \\
$50+$ & $0 \%$ \\
\hline
\end{tabular}

*Presuming optimum health 
In 2013, the JSRM launched an official “Q\&A” website about infertility issues designed for a general audience [22], which we have already mentioned in p. 5. Figure 9 shows a graph published in the website to answer the questions on how women's fertility declines with their age. The same graph has been used in professional publications, such as the 2014 version of the standard textbook for training doctors in reproductive medicine edited by the JSRM [23] and a handbook for doctors supervised by the chairperson of the executive board of the JSRM [24]. For the books, the chapters that included the graph were authored by Dr. Takahashi Toshifumi, now a professor at Fukushima Medical University.

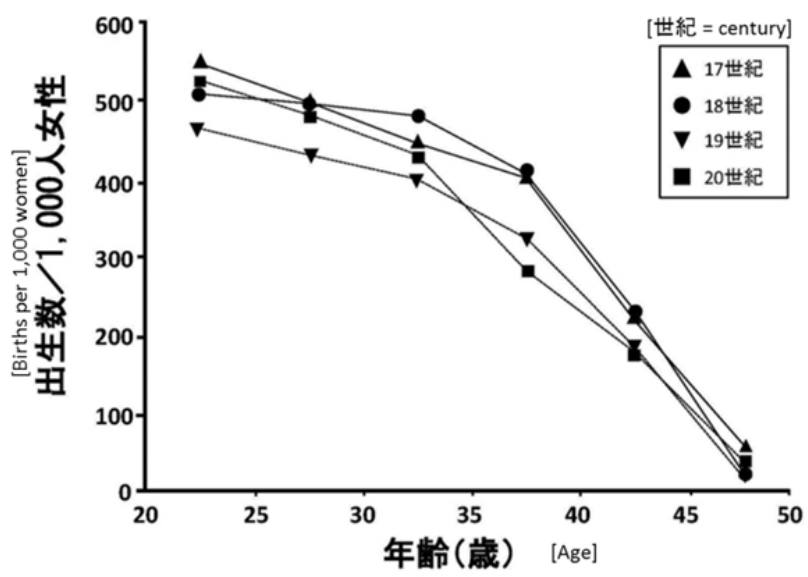

Source: http://www.jsrm.or.jp/public/funinsho_qa18.html

Figure 9: Four curves of age-specific marital fertility rates extracted by the Japan Society for Reproductive Medicine

The legend for the graph says that the curves are typical cases taken from the study by Menken et al. [45]. The original graph by Menken et al. showed 10 curves of age-specific marital fertility rates from various natural fertility populations (Figure 10). The JSRM extracted four curves from it to make Figure 9. In this process, the JSRM committed elementary mistakes [46]. The curve captioned " 17 th century" is in fact from the 20th century data. The curve captioned "20th century" is a composite of two series of the 17th and 19th century data.

Figure 9 gives the overall impression of its steep curves in contrast to the excluded curves. The excluded curves represent a common pattern of a round curve [1]. Their gradient is moderate during the 20 s and early 30 s and then becomes greater in the late 30s and after. By contrast, Figure 9 has an appearance of a rapid decrease in the fertility rate after the JSRM extracted curves with large gradients from the original. Particularly, the curve captioned "20th century" seems to decline almost linearly as the women age.

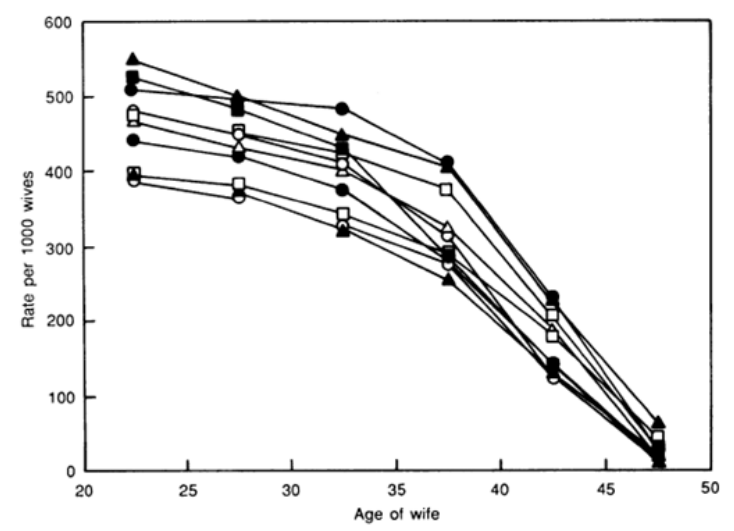

Fig. 1. Marital fertility rates by 5 -year age groups (5). The ten populations (in descending order at age 20 to 24) are Hutterites, marriages 1921-30

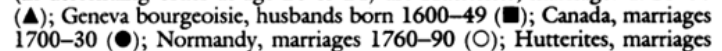
before 1921 ( $\square)$; Tunis, marriages of Europeans 1840-59 $(\Delta)$; Normandy, marriages 1674-1742 (9). Norway, marriages 1874-76 (D): Iran, village marriages, 1940-50( $(\Delta)$; Geneva bourgeoisie, husbands born before 1600 (O).

Source: Menken, Trussell, and Larsen [45].

Figure 10: Age-specific marital fertility rates in 10 natural fertility populations

The JSRM [23] also gives a wrong information about the data on which the graph is based. It explains the data as coming from a cohort study of North American Hutterites from the 16th to early 20th centuries. However, the study was in fact based on secondary data of 10 demographic records from various populations in Europe, Africa, Asia, and North America. Eight of the 10 populations were not North American Hutterites. Thereby, it is clear that the author and the JSRM editorial committee never confirmed the original figure by Menken et al. [45], whose description about the data sources contains European, African, and Asian geographical names as in Figure 10.

In December 2016, after the flaws in the graph were pointed out [46], JSRM's official website [22] discarded the graph. JSRM's textbook also dropped the graph from its 2017 edition [47]. Nevertheless, the JSRM has offered no explanation about how and why the graph was created and used. The same graph has still been featured in books, Web articles, and booklets published by local governments (see p. 11). 


\section{Undocumented Bayesian estimates of daily fecundability}

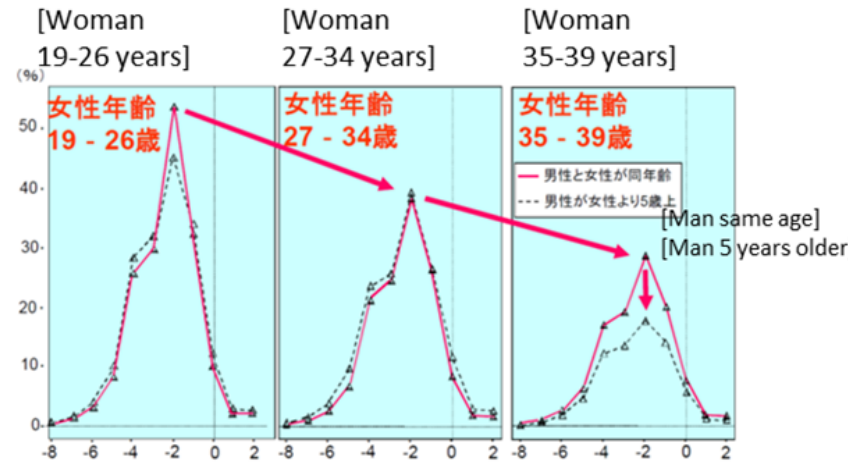

Source: Saito [50], a document prepared for a governmental conference. English text is from Dunson et al. [48].

Figure 11: Daily probability of conception, originally estimated by Dunson et al. [48]
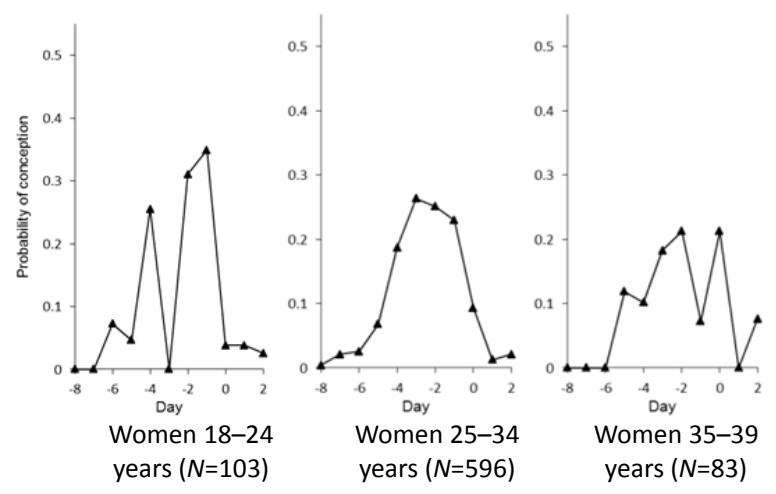

Created in accordance with the study by Colombo and Masarotto [49]. Also see Tanaka [1].

\section{Figure 12: Estimation of daily probability of conception from the European multicenter study (1992-1996)}

higher when the couple has intercourses more frequently. This suggests that the model may be biased toward estimating a greater probability of conception not only for the MFD, but also for younger couples owing to their frequent intercourses [1].

Thereby, the arbitrary modelling may exaggerate the peaks of the probability of conception, as well as its difference among the age classes. Indeed, the results reported in Figure 11 do not fit to the original data with no salient peak at 2 days before the ovulation (Figure 12). However, the details are not clear because there is not enough information available to replicate the method Dunson et al. [48] used.

These problems have been overlooked by researchers in the field of fertility study. A citation index search (with Web of Science in January 5,2017) revealed that among the 194 works citing Dunson et al. [48], only four papers cited Dunson [51], excluding self-citations. None of them discussed the flaws of the statistical model [1]. Thus, the study by Dunson et al. [48] has been referred to without methodological scrutiny at all. methods used for their estimation. It explains that they performed a Bayesian estimation; however, it does not give enough information about the model and prior distribution. Therefore, their estimation is not replicable.

As for the model for the estimation, a preceding paper by Dunson [51] has some information to guess the method to obtain the result shown in Figure 11. It describes the model construction under the a priori assumption of the "most fertile day" (MFD); each menstrual cycle has the special day called the MFD on which the probability of conception is especially higher than that in the other days. The model also implies that the estimated probability for the MFD will be even
Despite the lack of scrutiny on their validity, graphs, such as Figure 11, have served as if they were scientific evidence that fertility rapidly decreases with age. Referring to the findings of Dunson et al. [48], Kawai [52] stated that women's fertility in their late 30s is about one-half of that in the early 20s. Dr. Saito frequently used Figure 11 and similar graphs in governmental conferences for making the 2015 Outline of Measures against the Declining Birthrate as a ground for his argument that women's average age at childbirth should be lowered to $\leq 25$ years. 
Here is a summary of the history of the egg aging campaign and related discourses.

1974 “卵子の老化” (egg aging) was mentioned in a discussion at a symposium [3] by the Japanese Association of Medical Sciences (JAMS) (in Aug.). 1979 Dr. Suzuki [2] published an overview article on egg aging in Japanese.

1982 Dr. Suzuki [53] published the graph of the number of eggs by age (no citation), identical to Figure 3.

The term egg aging is found in a recorded discussion at a JAMS symposium in 1974. During such a period, this concept was used with the original meaning: degeneration of germ cells as a result of delayed fertilization. It was used to imply the increasing chromosomal abnormality along with advancing age of mothers. Another topic was the proliferation of female germ cells in a fetus and their subsequent disappearance. These biological arguments were not associated with birthrate decline of the country.

In the US, the faulty data of the declining probability of pregnancy (Tables 1 and 2) appeared in the late 1990s. These were not imported into Japan at that time.

1995 Rosenthal The Fertility Sourcebook (first edition)

1998 2nd ed. of Rosenthal's book [40] included Table 2.

1998 Carcio's book Management of the Infertile Woman [39] published Table 1.

2001 Dr. Yoshimura mentioned egg aging in a book targeting general audience [4].

2005 The Health and Global Policy Institute (HGPI) published a report on women's healthcare as a proposal to raise the national birthrate [54].

The HGPI's report in 2005 was the first case in public discourse that associated age-related fertility decline with the decline of the country's birthrate. It featured a round curve derived from the study of Menken et al. [45] (Figure 10) to describe the decline in women's biological fertility after their mid-30s.

In 2009, Dr. Asada published a book for a general audience. It said (without citation) that 1,000 eggs disappear from women's ovaries every month so that the stock of eggs runs out by the age of 37 years.

2009 Dr. Asada's book [25] introduced the linear decline in the number of eggs.

2009-2010 The IFDMS was conducted.

2011 Prof. Boivin visited Japan and had lectures on the IFDMS results for media and lawmakers (Feb.).

2011 FRaU (women's magazine by Kodansha) featured fertility issues [10] (July)
2012 NHK (Japan Broadcasting Corporation) TV programs about egg aging [5] (Feb. and June)

2012 Dr. Saito and Shirakawa's book on fertility issues and women's life [55] (Mar.)

2012 Noda Seiko cited the IFDMS in a question about education on fertility [11] at the Diet (Nov. 16).

2012 The 2nd Abe Shinzo Cabinet (Dec. 26)

2013 Dr. Yoshimura became an advisor to the Cabinet (Mar. 13).

2013 The Cabinet Office launched a taskforce to overcome the crisis of a low birthrate (Mar. 25).

2013 JSRM's website Infertility Q\&A [22] (Apr.)

2013 Dr. Yoshimura used the falsified graph of women's fertility with its peak at the age of 22 years [35] (June).

2014 Subsidization scheme for measures against regional problems related to the declining birthrate

2014 The National Governors' Association proposed a set of policies regarding population issues [56] (July).

2014 The JSRM published a textbook [23] for training of doctors specializing in reproductive medicine (Oct.).

2014-2015 Governmental committee to make the new administration outline against declining birthrates

2015 Petition by the JSOG and other eight associations [30] (Mar. 2)

2015 Outline of Measures against the Declining Birthrate [8] (Mar. 20)

2015 Supplementary textbook for health education in high schools [37] (Aug.)

After the result of the IFDMS was imported to Japan in 2011, discourse about egg aging and national birthrate developed. Books and magazines featured this issue. TV programs on such gained public attention.

The year 2013 was an epoch in terms of politics. The Second Abe Cabinet, launched in December 2012, appointed Dr. Yoshimura Yasunori as an advisor on measures to counter the declining birthrate and support child-raising in March 2013. It subsequently organized a taskforce to handle the low birthrate issue. These changes facilitated the medicalization of a population policy, through which obstetricians and gynecologists played a part as advisory experts.

\section{The 2015 Outline of Measures against the Declining}

Birthrate established the policy of disseminating medical knowledge on fertility and childbirth. Its provision was the basis for introducing medical contents about reproduction into school education. In August 2015, the government issued a supplementary textbook and distributed it to high schools. This textbook triggered criticism on the falsified graph (Figure 6). Subsequently, researchers have discovered a number of unscientific graphs used for the egg aging campaign, which we have already seen in this brochure. 


\section{Life-planning guidance by the government}

For the governmental pronatalist policy in the 2010s, "life planning" has been a key phrase. Various kinds of activities have been conducted to encourage youths to make a life plan regarding marriage, children, and other family issues. Lectures and textbooks are prepared for young men and women to guide their choices, as well as public-subsidized services to offer suitable arrangements for those seeking potential marriage partners [14].

An instance of such activities was the above-mentioned supplementary textbook for health education in high school [37]. In addition, local governments have been involved in life-planning guidance for youths.

The central government of Japan established a scheme of subsidy for projects to solve regional population problems by the initiative of each local government. The supplemental budget of fiscal 2013 introduced the scheme of financial support for countermeasures against regional problems related to the declining birthrate (地 域少子化対策強化交付金). It subsidizes such a kind of projects as providing information for those seeking potential marriage partners, holding lectures on life planning, and publishing media contents to teach medical knowledge about fertility. Local governments make proposals based on their own analysis of the population problems they face.

Before this subsidization scheme started, some local governments had made their own effort to develop life-planning education. There had been two roots of such efforts. One was an effort to prevent unintended pregnancy and promote reproductive health/rights [57]. The other focused on liberation from gender roles to realize gender equality through work/family decision-making [58].

Since 2014, the new subsidization scheme encouraged local governments to offer the residents information for their life planning. Various booklets, leaflets, websites, movies, and mobile applications have been produced utilizing financial supports from the central government. Notwithstanding the wide variety in their contents, style, and orientation, those products commonly feature medical knowledge about fertility as an important resource for youths' life planning. Many of them contain the graphs we have already seen.

Among visual representations featured in the publications, we can find cases of deterioration owing to repeated duplications without referring to the original.

For example, the falsified graph of women's fertility we have seen in Figure 6 was used in Nara Prefecture's life-planning booklet [59]. It is obvious that the writers of the booklet did not check the original paper; as such, they could not notice the fact that the graph had been falsified. In addition, they reproduced it from a YouTube movie [60], resulting in an inaccurate copy of the already falsified graph. A further distorted version of the graph (Figure 13) is found in the website of Mie Prefecture [61]. It exhibits a winding curve with a taste of handwriting. Although no source is mentioned, it maintains the characteristics of the series of graphs rooted in Bendel and Hua's study on natural fecundability [29] in which the curve peaks at the age of 22 years and then rapidly decreases.

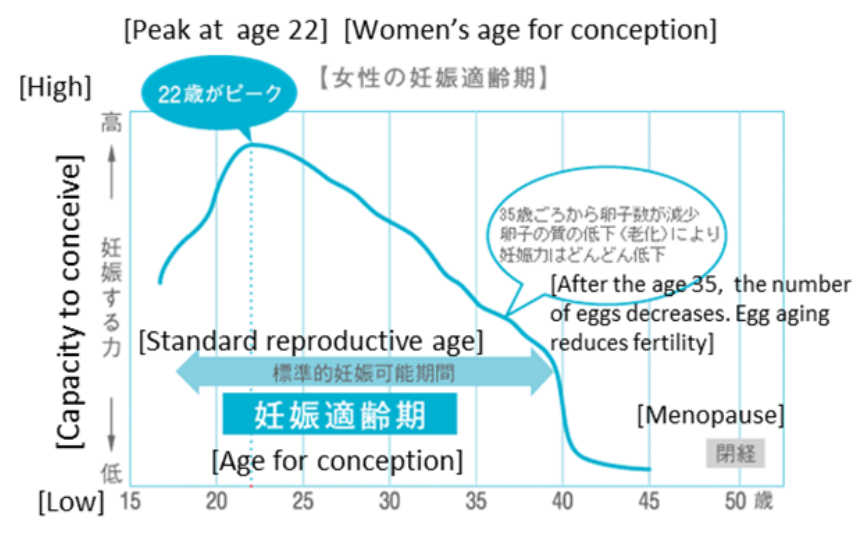

Source: Mie Prefecture website [61]. English translation is mine.

Figure 13: Handwriting-taste curve of women's fertility

There is another series of graphs perfunctorily copied without referring to the original study. We have already seen the manipulated graph of the number of eggs (Figure 2) as a product of a research project funded by the government [16] [17]. The graph provides citation as "Acta Endocrinol Sullpl," which is obviously an incorrect abbreviation for the journal Acta Endocrinologica Supplementum. This citation mistake has been repeated over the generations of copies of the graph published by local governments [62] [63] as well as the inaccurate values on the axes and the curve.

Local governments now continue making and broadcasting this kind of information, utilizing a huge budget backed by the central government of Japan for countermeasures against the shrinking population. Even supervised by professionals, it is a hotbed of unscientific knowledge. Distorted graphs are being reproduced for the sake of the visual impact on audience. There is no checking system functioning; authors and supervisors do not access the literature to confirm the original data for the graph they are citing. 


\section{References}

1. Tanaka S (2017) Another science war. Advances in gender research 24

2. 鈴木秋悦 (1979). 卵子の異常. 代謝 16(202): 1463-1467.

3. 日本医学会 (1975) 初期発生 (II). 日本医師会雑誌 74(8): 891-946.

4. 吉村泰典 (2001) やっぱり赤ちゃんが欲しい. 主婦と生活社.

5. NHK 取材班 (2013) 産みたいのに産めない. isbn:9784163763606

6. 河合蘭 (2015) 助産雑誌 69(5): 410-415. doi:10.11477/mf.1665200202

7. 増田美加 (2017) 卵子の老化は 30 代からスタートし、30 代後半には 加速する! あなたの卵巣力は?. Mylohas 2017.08.08. https://www.mylohas.net/2017/08/063996bodystrategy05.html

8. 内閣府 (2015) 少子化社会対策大綱 (3 月 20 日閣議決定). http://www8.cao.go.jp/shoushi/shoushika/law/taikou2.html

9. Bunting L, Tsibulsky I, Boivin J (2013) Fertility knowledge and beliefs about fertility treatment. Human reproduction 28(2):385-397.

10. 講談社 (2011) FRaU body: 妊活スタートブック. isbn:9784063895759

11. 野田聖子 (2012) 第 181 回国会 質問 50 号. http://www.shugiin.go.jp /internet/itdb_shitsumon.nsf/html/shitsumon/a181050.htm

12. 齊藤英和 (2014). 妊娠適齢期を意識したライフプランニング. (新た な少子化社会対策大綱策定のための検討会 第 3 回) http://www8.cao. go.jp/shoushi/shoushika/meeting/taikou/k_3/pdf/s2-1.pdf

13. Tanaka S. (2016). Misinformation due to a low-quality international multilingual survey. doi:10.31219/osf.io/q6fx8

14. 西山千恵子，柘植あづみ (ed.) (2017) 文科省／高校「妊活」教材の嘘 論創社. isbn: 9784846016265

15. 高橋さきの (2015) 「妊娠しや寸さ」グラフはいかにして高校保健 ・ 副教材になったのか. Synodos. http://synodos.jp/education/15125

16. 厚生労働省 (2013) 知っていま寸か? 男性のからだのこと、女性のか らだのこと: 健康で充実した人生のための基礎知識。

http://www.mhlw.go.jp/seisakunitsuite/bunya/kodomo/kodomo_ko sodate/boshi-hoken/dl/gyousei-01-01.pdf

17. 山縣然太朗 (2013) 母子保健事業の効果的実施のための妊婦健診、乳 幼児健診データの利活用に関する研究. https://mhlw-grants.niph. go.jp/niph/search/NIDD00.do?resrchNum=201219019A

18. Baker TG (1971) American journal of obstetrics \& gynecology 110: 746-761. doi:10.1016/0002-9378(71)90271-7

19. Baker TG (1972) Acta endocrinologica supplementum 166: 18-41.

20. Baker TG (1963) Proceedings of the Royal Society of London. Series B, biological sciences 158: 417-433. doi:10.1098/rspb.1963.0055

21. Block E (1952) Acta anatomica 14: 108-123. doi:10.1159/000140595

22. 日本生殖医学会 (2013) 不妊症 Q\&A.

http://www.jsrm.or.jp/document/funinshou_qa.pdf (June 26)

23. 日本生殖医学会 (2014) 生殖医療の必修知識. isbn:9784990798802

24. 吉村泰典 (supervisor) (2014) 生殖医療ポケットマニュアル. 医学書院.

25. 浅田義正，松島美紀 (2009) 卵子の話. シオン. isbn:9784903598116

26. Faddy MJ, Gosden RG, Gougeon A, et al. (1992) Human reproduction 7(10): 1342-1346. doi:10.1093/oxfordjournals.humrep.a137570

27. 小池浩司 (2000) 卵巣機能不全 (特集:第 52 回日本産科婦人科学会生 涯研修プログラム). 日本産科婦人科学会雜誌 52(9): N278-N281

28. te Velde ER, Dorland M, Broekmans FJ (1998) Maturitas 30: 119-125.

29. Bendel JP, Hua CI (1978) Social biology 25(3): 210-227.

30. 日本家族計画協会 (2015) 本会 ・ 日本産科婦人科学会など 9 団体 学 校教育の改善求め要望書提出. 家族と健康 732: 1 .

31. Sheps MC (1965) Population studies 19(1): 65-80.

32. Tanaka S (2017) 東北大学文学研究科年報 $66: 142-128$.

33. Wood JW (1989) Oxford reviews of reproductive biology 11: 61-109.

34. O'Connor KA, Holman DA, Wood JW (1998) Maturitas 30: 127-136.

35. 吉村やすのり (2013) 卵子の老化-続報- 女性の年齢と妊孕力との関 係. http://yoshimurayasunori.jp/blogs/2013/06/25/

36. James WH (1979) Social biology 26(4): 330-334.

37. 文部科学省 (2015) 健康な生活を送るために (平成 27 年度版). http:/ /www.mext.go.jp/a_menu/kenko/hoken/08111805.htm (Aug. 22)

38. Tanaka S (2016) The origin of a chart indicating the likelihood of conception linearly declining with age. doi:10.31235/osf.io/huk49

39. Carcio HA (ed.) (1998) Management of the infertile woman. Lippincott.

40. Rosenthal MS (1998) The fertility sourcebook (2nd ed.). Lowell House.

41. Henry L (1961) Some data on natural fertility. Eugenics quarterly 8(2).

42. Coale AJ, Trussell TJ (1974) Population index 40(2): 185-258.

43. Phillips K, Grifo J (2016) The whole life fertility plan. William Morrow.

44. 福岡市 こども未来局 総務企画課 (2018) 未来へのプロセス. http://www.dankk.co.jp/lifeplan/course.html

45. Menken J, Trussell J, Larsen U (1986) Age and infertility. Science 233.

46. Tanaka S (2016) Menken ほか (1986) の Science 論文から「代表的 なデータを抜粋」したと称する日本生殖医学会サイトのグラフについ て.http://d.hatena.ne.jp/remcat/20160430
47. 日本生殖医学会 (2017) 生殖医療の必修知識 2017 .

48. Dunson DB, Colombo B, Baird DD (2002) Human reproduction 17(5): 1399-1403. doi:10.1093/humrep/17.5.1399

49. Colombo B, Masarotto G (2000) Demographic research 3(5).

50. 齊藤英和 (2015) 資料 $3(2 / 5)$ (新たな少子化社会対策大綱策定のため の検討会 第7回). http://www8.cao.go.jp/shoushi/shoushika/meeting /taikou/k_7/

51. Dunson DB (2001) Biometorics 57(4): 1067-1073.

52. 河合蘭 (2013) 卵子老化の真実. 文藝春秋. isbn:9784166609062

53. 鈴木秋悦 (1982) ヒトの受精のタイミング. 講談社. isbn:4061394789

54. 日本医療政策機構 (2005) 少子化と女性の健康. http://www.hgpi.org/handout/2010-04-16_33_998301.pdf

55. 齊藤英和，白河桃子 (2012) 妊活バイブル. 講談社.

56. 全国知事会 (2014) 少子化非常事態宣言. http://www.nga.gr.jp/data/document/2014/1406881342915.html

57. 佐賀県 (2010) ファミリープラン: 健やかな妊娠のために. http://www.pref.saga.lg.jp/kiji00334035/3_34035_3_201114141933.pdf

58. 鳥取県 福祉保健部子育て支援総室 (2010) 女と男の幸せガイド. http://www.pref.tottori.lg.jp/secure/531020/otokotoonna.doc.pdf

59. 奈良県 医療政策部 (2015) 今 伝えたい!! 将来のあなたへ (初版) http://www.pref.nara.jp/secure/139347/マイライフプラン冊子.pdf

60. 厚生労働省 (2014) 妊娠と不妊について.http://tsigeto.info /misconduct/yoshimura-2014-mhlw/ (Retrieved from Youtube MHLW Channel).

61. 三重県 子ども・福祉部 (n.d.) 将来のために知っておきたい妊娠のこ と.http://www.pref.mie.lg.jp/D1KODOMO/sisyunki/000125751.htm

62. 秋田県 (2017) 考えよう ライフプランと地域の未来. http:/ /common3.pref.akita.lg.jp/babywave/detail.php?id=1493099802421

63. 神奈川県 健康医療局 健康増進課 (2015) 卵子の数は減っていく(1) http://www.okanouenooisyasan.com/knowledge/ovum/01/

(See the reference list on $h t t p: / /$ tsigeto.info/18k for details.)

\section{Information wanted}

The project “Unscientific knowledge and the egg aging panic" is collecting information on unscientific discourses about human reproduction, especially those used with the political intention to raise fertility. If you notice any dubious graph, data, and explanation with scientific authority, please report such.

The author's webpage http://remcat.tsigeto.info offers the search function for information already collected by the project. News and research results will be on the project URL below. Social media accounts are also accessible via the website.

Unscientific Visual Representations Used for the "Egg Aging" Campaign in 2010s Japan Project "Unscientific Knowledge and the Egg Aging Panic" Research Report I

Author: TANAKA Sigeto (田中重人)

Publisher: Tanaka Sigeto Laboratory (田中重人研究室)

Address: School of Arts and Letters, Tohoku University. Kawauti 27-1, Sendai, Miyagi 980-8576, JAPAN

E-mail: tsigeto@tohoku.ac.jp

Author URL: http://tsigeto.info/office.html

Project URL: http://tsigeto.info/egg/

Publication URL: http://tsigeto.info/18k

DOI: $10.31235 /$ osf.io/xyvsa

Publication Date: 2018-05-11 (draft); 2018-08-27 (ver. 1)

Copyright (C) 2018 Tanaka Sigeto

ISBN978-4-9910316-0-1 